Abstracta Iranica Abstracta Iranica

Revue bibliographique pour le domaine irano-aryen

Volume 29 | 2008

Comptes rendus des publications de 2006

\title{
«Symbolic Door Stelae and Graveside Monuments in Western Anatolia ». AJA, 110/1, 2006, pp. 65-91.
}

\section{Astrid Nunn}

\section{(2) OpenEdition}

1 Journals

\section{Édition électronique}

URL : http://journals.openedition.org/abstractairanica/26252

DOI : 10.4000/abstractairanica.26252

ISSN : 1961-960X

Éditeur :

CNRS (UMR 7528 Mondes iraniens et indiens), Éditions de l'IFRI

\section{Édition imprimée}

Date de publication : 15 mai 2008

ISSN : 0240-8910

\section{Référence électronique}

Astrid Nunn, « «Symbolic Door Stelae and Graveside Monuments in Western Anatolia ». AJA, 110/1, 2006, pp. 65-91. 》, Abstracta Iranica [En ligne], Volume 29 | 2008, document 87, mis en ligne le 15 septembre 2008, consulté le 26 septembre 2020. URL : http://journals.openedition.org/ abstractairanica/26252 ; DOI : https://doi.org/10.4000/abstractairanica.26252

Ce document a été généré automatiquement le 26 septembre 2020.

Tous droits réservés 


\section{«Symbolic Door Stelae and Graveside Monuments in Western Anatolia ». AJA, 110/1, 2006, pp. 65-91.}

\section{Astrid Nunn}

Cet article présente un groupe de 19 monuments funéraires particuliers à l'Anatolie de l'Ouest du VI $\mathrm{I}^{\mathrm{au}} \mathrm{IV}^{\mathrm{e}} \mathrm{s}$. av. J.-C. Ces monuments ont tous la forme d'une porte, sans en être une. Ils indiquaient plutôt l'existence d'une tombe, qu'elle soit un tumulus ou creusée dans le roc. Les passants pouvaient ainsi faire une offrande aux défunts. Ces portes ne se distinguent que par leurs styles qui oscillent entre les influences plus ou moins marquées des arts phrygien, grec et perse achéménide. Le groupe A qui remonte au $\mathrm{VI}^{\mathrm{e}} \mathrm{s}$. montre une porte embellie de structures architecturales. Le groupe B, plus récent, incorpore des éléments de stèles à frises de fleurs et de palmettes (anthemion). Deux monuments portent une inscription qui nomme le défunt propriétaire de la tombe. 17 des 19 monuments proviennent de Lydie - 7 d'entre eux de Sardes - ce qui indique que ce type en est originaire, le mélange de styles étant de plus caractéristique de cette région. La porte est évidemment une partie architecturale très symbolique. Elle s'ouvre sur la vie après la mort et permet aux vivants d'être en contact avec les membres de leur famille décédés et avec leurs ancêtres.

\section{INDEX}

Thèmes : 3.2.2. Pré-Achéménides et Achéménides 
AUTEURS

ASTRID NUNN

Université de Munich 